\title{
The Effect of Lentinus squarrosulus, (Mont.) Consumption on the treatment of Gastritis in Male Wistar Rats
}

\section{Buavaroon Srichaikul*}

\section{Buavaroon Srichaikul*}

Faculty of Public Health, Mahasarakham University, Mahasarakham 44150, THAILAND.

\section{Correspondence}

\section{Buavaroon Srichaikul}

Faculty of Public Health, Mahasarakham University, Mahasarakham 44150

THAILAND.

E-mail: buacanada@gmail.com

History

- Submission Date: 03-05-2020

- Review completed: 25-06-2020;

- Accepted Date: 01-07-2020.

DOI : $10.5530 / \mathrm{pj} .2020 .12 .154$

Article Available online

http://www.phcogj.com/v12/i5

Copyright

(C) 2020 Phcogj.Com. This is an openaccess article distributed under the terms of the Creative Commons Attribution 4.0 International license.

\begin{abstract}
Introduction: Gastritis or /and gastric ulcers are one of the most common symptoms which occur in a large amount of the population. It results in a very high amount of medication expense. This study investigated the prevention and treatment of gastritis or /and gastric ulcer actions using white log mushroom (Lentinus squarrosulus, (Mont.). Methods: White wistar rats were induced with $100 \%$ absolute alcohol to be effective for gastritis and /or ulceration within rats. The gastric lesions of white wistar rats were investigated and calculated the lesions of stomach areas under microscopic method. The results were calculated and a comparative study among white wistar rats. Ulcer prevention and ulcer healing properties were administrated though a dose of $250 \mathrm{mg} / \mathrm{kg}$ of $L$. squarrosulus extract and $L$. squarrosulus compared with $50 \mathrm{mg} / \mathrm{kg}$ of Ranetidine. Results: It was found that Lentinus squarrosulus, (Mont.) consisted of Beta-glucan was the active ingredient creating a healing effect. It showed a result of $100 \%$ healing effect in gastritis and/or ulcers in which it had similar healing effects between extracted solutions of white log mushroom ( $250 \mathrm{mg} / \mathrm{kg}$ body wt.) The healing activity also showed the equivalent effect compared to Ranetidine $150 \mathrm{mg}$. Conclusions: Extracted solution of white log mushroom showed prevention and treatment efficacy in gastritis and/ or ulcer are equivalent to Ranetidine $150 \mathrm{mg}$. A similar dose of $250 \mathrm{mg} / \mathrm{kg}$ of $L$. squarrosulus extract and $L$. squarrosulus snack can prevent and heal ulcers and is more effective than Ranetidine.
\end{abstract}

Key words: L. squarrosulus, Ulcer prevention, Ulcer healing, Beta glucan, Ranetidine 150 mg.

\section{INTRODUCTION}

Mushrooms have highly nutritious compounds, which are used to prevent and treat disease and the ingredients can be used in supplements. Especially, peptic ulcer or gastritis disease occurring from the infection of Helicobacter pyrola as a Gram-negative bacteria in the human stomach $^{1-6}$ and administration of Non-steroidal Anti-inflammatory drugs (NSAIDs). These drugs are used for the treatment of pain, rheumatic, and cardiovascular diseases. Regular use of NSAIDs will inhibit an action of Prostaglandins which can affect the digestive system, liver, cardiovascular system and respiratory system and also the central nervous system..$^{7-10}$ found that there are increasing numbers of gastritis and ulcer incidences throughout the world.

White log mushroom has high nutritional values and no fat which are essentials for human body such as protein, carbohydrate, selenium, iron, magnesium, potassium, zinc, manganese, vitamin, vitamin, vitamin $B 1$, vitaminB2, vitamin. ${ }^{3,7}$ The contents of white log mushroom consist of twice the protein than vegetable leaves and or an oat $\operatorname{diet}^{9}$ including higher potassium in order to decrease in anti-hypertension. ${ }^{9,7,4}$ mentioned that it has high antioxidant levels which can have a healing effect in preventing and curing the gastric ulcer and also $^{8,7}$ found an increase of human immunity and longevity (Thailand Department of Traditional and Alternative Medicine Ministry of Public Health
2013). Active ingredients in white log mushroom are phenolic, tannin and flavonoids. ${ }^{7,4}$ polysaccharide, and triterpenoid.etc. Reported that mushroom in Lentinus family contain high amounts of Beta glucan which is called lentinans. Lentinans has an anticancer property and is a high immunity modulator and also has high antioxidant activity which are confirmed by DPPH Assay analysis. ${ }^{11}$ In 2011, we found that white $\log$ mushroom can give the prevention of gastritis or ulcer action. The hot water extraction of white log mushroom solution contained protein $(57.6 \mathrm{~g} / 100$ g) carbohydrate, selenium, iron, magnesium, potassium, zinc, manganese, vitamin $\mathrm{A}$, vitamin $\mathrm{E}$, Vitamin B1, vitamin B2 vitamin B3.

\section{MATERIALS AND METHODS}

\section{Study area}

The experiment was carried out in November 2018 to March 2019 at animal laboratory faculty of sciences, Khon khan University

\section{Preparation of L. squarrosulus extract}

L. squarrosulus was obtained from mushroom farm at Ban Dong, Wongong Sub-district, Muang Mahasarakham, Maha Sarakham. L. squarrosulus samples were extracted by water at a ratio of $1: 1$ and boiled for 30 minutes. The broth was centrifuged at $3000 \mathrm{~g}$ for 15 minutes and the supernatant was filtered using Whatman no. 1 filter paper. The water extract was freeze dried. 


\section{Preparation of $L$. squarrosulus (Mont.) snack}

White log mushroom $10 \mathrm{~kg}$ were washed with purified water and were processed using a freeze drying machine for $4-5$ hours. The freeze dried white log mushroom was grinded and mixed with starch and flavouring powder to taste. The products were made into layered sheets and were cut into thin pieces and put into an oven in order to make them crispy. They were kept in sealed containers awaiting further testing.

\section{Preparation of wistar rat subjects}

Adult male wistar rats aged 6-8 weeks and weighed between 180 and $200 \mathrm{~g}$ were purchased from Northeast Laboratory Animal Centre, Khon Kaen University, Thailand. The animals were housed at $27 \pm 2^{\circ} \mathrm{C}$ temperature, fed with standard laboratory pellets, and provided with water ad libitum.

\section{Ulcer prevention property}

A total of 24 of SD rats were divided randomly into four groups comprised of six rats in each group. All groups were deprived of food for 24 hours before the experiment. The experiment began with pretreatments according to the assigned group:

Group 1 (ulcer control) received the vehicle (distilled water) only

Groups 2 received L. squarrosulus extract $250 \mathrm{mg} / \mathrm{kg}$

Groups 3 received L. squarrosulus snack $250 \mathrm{mg} / \mathrm{kg}$

Groups 4 received (positive control) $50 \mathrm{mg} / \mathrm{kg}$ of ranetidine $150 \mathrm{mg}$.

All wistar rat subjects were administered with absolute ethanol after thirty minutes of the pretreatment. After an additional thirty minutes, all subjects were examined and their stomachs were removed and kept immersed in $10 \%$ of buffered formalin before the analysis of gastric lesions.

\section{Ulcer healing property}

A total of $24 \mathrm{SD}$ rats were divided randomly into four groups comprising six rats in each group:

Group 1 animals which served as normal control received vehicle (distilled water) only.

Groups 2, 3 and 4 (ulcerated groups) were pre fasted for 24 hours before inducing ulcer using absolute ethanol $(5 \mathrm{~mL} / \mathrm{kg})$.

Group 2 was treated with L. squarrosulus extract at a dose of $250 \mathrm{mg} / \mathrm{kg}$

Group 3 was treated with L. squarrosulus snack at a dose of $250 \mathrm{mg} / \mathrm{kg}$

Group 4 was treated with $50 \mathrm{mg} / \mathrm{kg}$ ranetidine $150 \mathrm{mg}$ (positive control).

All groups were treated once daily in the morning. One rat per group was examined after a 24 hour treatment. The stomach tissues were homogenized with phosphate buffer saline (PBS). Both serum and tissue homogenates were stored at $-80^{\circ} \mathrm{C}$ for analysis.

\section{Gross evaluation of gastric lesions}

Each stomach was incised along a greater curvature and rinsed with distilled water to remove gastric contents. The stomach was examined under a dissecting microscope $(1.8 \mathrm{x})$ with a square grid eyepiece. (Big square: length $\times$ width $=10 \times 10 \mathrm{~mm}^{2}=$ ulcer area) to access the formation of ulcerated area (hemorrhagic lesions). The sum of all lesions, in $\mathrm{mm}^{2}$, for each stomach was expressed as the ulcer area $\left(\mathrm{mm}^{2}\right)$. The percentage of inhibition (\%) was calculated by the following formula Omar:

$$
\% \text { inhibition is equal to } \frac{\text { UAcontrol - UAtreated }}{\text { UAcontrol }} \times 100
$$

\section{Statistical analysis}

The results were expressed as mean \pm S.E.M. Statistical differences among groups were evaluated by Dunnett's multiple comparison test. Student's t-test was applied to comparisons between two groups. $\mathrm{P}$ values of $<.05$ were considered significant.

\section{RESULTS AND DISCUSSION}

\section{Prevention of ulcer}

The result showed $L$. squarrosulus extract and $L$. squarrosulus snack reduced the formation of gastric ulcers induced by ethanol and can inhibit more than ranetidine $150 \mathrm{mg}$. The inhibition percentage of ulcer area was $100 \%, 88 \%$, and $84 \%$ respectively (Table 1, Figure 1 ).

\section{Healing of ulcer}

After administration of $250 \mathrm{mg} / \mathrm{kg}$ of $L$. squarrosulus extract and $L$. squarrosulus snack for 48 hours increases the healing of gastric ulcer in ethanol-induced rats. This study found that $L$. squarrosulus extract, $L$. squarrosulus snack and ranetidine $150 \mathrm{mg}$ can decrease the ulcer area by $100 \%, 86 \%$, and $81 \%$ respectively (Table 2 ).

The comparative of efficacy of L. squarrosulus White Log Mushroom and White Log Mushroom Snack and Ranetidine $150 \mathrm{mg}$. in prevention and treatment of gastric ulcers and gastritis in wistar rats found that induced absolute alcohol wistar rats had the result of $81-100 \%$ healing effect of gastritis and ulcer which was equal to ranitidine $150 \mathrm{mg}$. Other studies showed that Beta glucan in white log mushroom had an inhibition action of histamine secretion from gastric cells which can decrease the secretion of gastric acid or HCL. ${ }^{7}$ It was experimented in 125, 125, 250 and $500 \mathrm{mg} / \mathrm{kg}$ of white mushroom extraction administered to wistar rats found that the healing effect of induced absolute alcohol ulcer wistar rats have equivalent activity with Ranetidine $150 \mathrm{mg}$ efficacy. The maximum healing result was found in using dosage of $250 \mathrm{mg} / \mathrm{kg}$ white mushroom extraction administered to wistar rats which had positive efficacy equivalent to ranetidine $150 \mathrm{mg}$.
A
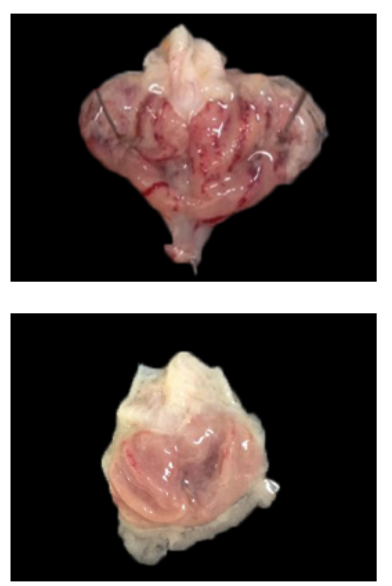

$\mathrm{C}$
B
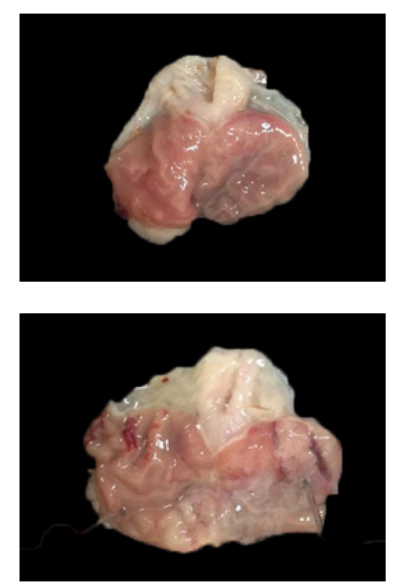

$\mathrm{D}$
Figure 1: Show wistar rats with induced absolute ethanol gastritis ( $A=$ control wistar rats) $B=$ wistar rats with administered white log mushroom extraction $250 \mathrm{mg} / \mathrm{kg} \mathrm{C}=$ wistar rats with administered white log mushroom extraction $250 \mathrm{mg} / \mathrm{kg}$ from white mushroom snack $D==$ wistar rats with administered ranetidine $150 \mathrm{mg}$ at dosage of $50 \mathrm{mg} / \mathrm{kg}$ body weight. 
Table 1: Prevention of gastric ulcer (Mean \pm SEM; $\mathbf{n = 6 )}$.

\begin{tabular}{ccc}
\hline Treatment & Ulcer area $\left(\mathrm{mm}^{2}\right)$ & \% Inhibition \\
\hline Distilled water & $181.90 \pm 13.38^{\mathrm{c}}$ & - \\
L. squarrosulus extract at dose $250 \mathrm{mg} / \mathrm{kg}$ & - & 100 \\
L. squarrosulus snack at dose $250 \mathrm{mg} / \mathrm{kg}$ & $20.47 \pm 6.89^{\mathrm{ab}}$ & 88 \\
ranetidine150mg at dose $50 \mathrm{mg} / \mathrm{kg}$ & $28.85 \pm 4.14^{\mathrm{b}}$ & 84 \\
\hline
\end{tabular}

All values were expressed as mean and \pm standard error mean of six replicates of wistar rats. Means with different superscripts was significantly different $(P<.05)$.

Table 2: Healing of Ulcer of gastric ulcer (Mean SEM; $n=6)$.

\begin{tabular}{ccc}
\hline Treatment & Ulcer area $\left(\mathrm{mm}^{2}\right)$ & \% Inhibition \\
\hline Distilled water & $135.72 \pm 3.72^{\mathrm{b}}$ & - \\
L. squarrosulus extract at dose $250 \mathrm{mg} / \mathrm{kg}$ & - & 100 \\
L. squarrosulus snack at dose $250 \mathrm{mg} / \mathrm{kg}$ & $17.68 \pm 12.20^{\mathrm{a}}$ & 86 \\
ranetidine150mg at dose $50 \mathrm{mg} / \mathrm{kg}$ & $25.55 \pm 16.44^{\mathrm{a}}$ & 81 \\
\hline
\end{tabular}

Also, It has been shown that mushroom extracts revealed similar electrochemical responses, suggesting similar electroactive chemical composition, and oxidation potentials more positive than those of the standards (ascorbic and gallic acids). ${ }^{2}$ Some research has been reviewed in case of antidiabetic property of mushrooms. Therefore, it is proposed further research of functional mushrooms for preventive and curative measures for diabetes and its complications. ${ }^{5}$ This study demonstrated that both a dose $250 \mathrm{mg} / \mathrm{kg}$. Of $L$. squarrosulus extract and $L$. squarrosulus snack can prevent and healing ulcers and more effective than ranitidine $150 \mathrm{mg}$.

\section{SIGNIFICANCE STATEMENT}

My findings have revealed that there is an active ingredient named Beta Glucan in White log mushroom (Lentinus squarrosulus) which can produce the efficacy of healing effect in gastro intestinal tract infection. It can reduce gastritis and similar results of actions using Ranetidine $150 \mathrm{mg}$. in Male Wistar Rats.

\section{ACKNOWLEDGMENTS}

The authors would like to thank Agricultural Research Development Agency (Public Organization) for financial support. The grant number is CRP6005020370.

\section{AUTHORS' CONTRIBUTION}

Experimental Areas referring to comparative ulceration healing efficacy between White log mushroom and Ranetidine $150 \mathrm{mg}$.

\section{CONFLICTS OF INTEREST}

None.

\section{LIVEDNA}

$66.14375^{*}$

\section{REFERENCES}

1. Abdullah N, Lau CC, Ismail SM. Potential use of Lentinus squarrosulus mushroom as fermenting agent and source of natural antioxidant additive in livestock feed. Journal of the Science of Food and Agriculture. 2016;96(5):145966.

2. Cheung LM, Cheung PC, Ooi VE. Antioxidant activity and total phenolics of edible mushroom extracts. Food chemistry. 2003;81(2):249-55.

3. Deng $\mathrm{C}, \mathrm{Hu} \mathrm{Z}, \mathrm{Fu} \mathrm{H}, \mathrm{Hu} \mathrm{M}, \mathrm{Xu} X$, Chen J. Chemical analysis and Antioxidant activity in vitro of a $\beta$-d-glucan isolated from Dictyophora indusiata. International Journal of Biological Macromolecules. 2012;51(1-2):70-5.

4. Ghate SD, Sridhar KR. Bioactive Potential of Lentinus squarrosulus and Termitomyces clypeatus from the Southwestern region of India. Indian Journal of Natural Products and Resources. 2017;8(2):120-31.

5. Kim YW, Kim KH, Choi HJ, Lee DS. Anti-diabetic activity of $\beta$-glucans and their enzymatically hydrolyzed oligosaccharides from Agaricus blazei. Biotechnology Letters. 2005:27(7):483-7.

6. Komoto K, Haruma K, KamadaT, Tanaka S, Yoshihara M, Sumii K, et al. Helicobacter pylori infection and gastric neoplasia: correlations with histological. gastritis and tumor histology. American Journal of Gastroenterology.1998;93(8):1271-6.

7. Mhd Omar NA, Abdullah N, Kuppusamy UR, Abdulla MA, Sabaratnam V. Nutritional Composition. Antioxidant Activities, and Antiulcer Potential of Lentinus squarrosulus (Mont.) Mycelia Extract. Evidence-based complementary and alternative medicine: eCAM, 2011:539356.

8. Pihan G, Regillo C, Szabo S. Free radicals and lipid peroxidation in ethanolor aspirin-induced gastric mucosal injury. Digestive Diseases and Sciences. 1987;32(12):1395-401.

9. Shimada K, Fujikawa K, Yahara K, Nakamura T. Antioxidative properties of xanthan on the autoxidation of soybean oil in cyclodextrin emulsion. Journal of Agricultural and Food Chemistry. 1992;40(6):945-8.

10. Wolfe MM, Lichtenstein DR, Singh G. Gastrointestinal toxicity of nonsteroidal anti-inflammatory drugs. New England Journal of Medicine. 1999;340(24):1888-99.

11. Zhu F, Du B, Bian Z, Xu B. Beta-glucans from edible and medicinal mushrooms: characteristics, physicochemical and biological activities. Journal of Food Composition and Analysis. 2015;41:165-73. 


\section{ABOUT AUTHORS}

\section{Buavaroon Srichaikul}

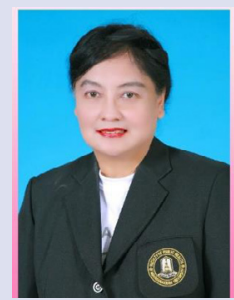

\begin{tabular}{|c|c|c|c|}
\hline Year & Degree & Specialization & Institution \\
\hline 2015 & $\begin{array}{c}\text { Certificate of completion } \\
\text { at Judge Business } \\
\text { School, University of } \\
\text { Cambridge, U.K. }\end{array}$ & $\begin{array}{c}\text { Business Plan Settling } \\
\text { Model of Pharmaceutical } \\
\text { products }\end{array}$ & $\begin{array}{c}\text { University } \\
\text { U.K. }\end{array}$ \\
\hline 2009 & $\begin{array}{c}\text { Post Doctorate in } \\
\text { Pharmaceutic Sciences }\end{array}$ & $\begin{array}{c}\text { Licencing The Pharmacy } \\
\text { Examining Board of } \\
\text { Canada } \\
\text { (PEBC) }\end{array}$ & $\begin{array}{c}\text { Toronto Institute of } \\
\text { Pharmaceutical Science, } \\
\text { TORONTO, CANADA }\end{array}$ \\
\hline 1999 & $\begin{array}{c}\text { Doc. of Health } \\
\text { Administration. }\end{array}$ & Health Management & Mahidol University \\
\hline
\end{tabular}

\section{Working Experience}

\begin{tabular}{|c|c|c|}
\hline 2018 & Assoc.Prof. Dr. at Faculty of Public Health. & Mahasarakham University, Thailand. \\
\hline 009 & $\begin{array}{l}\text { Lecturer at Toronto Institution of Pharmaceutical } \\
\text { Science, Toronto, Canada. }\end{array}$ & $\begin{array}{l}\text { Toronto Institute of Pharm } \\
\text { Science, Toronto, Canada. }\end{array}$ \\
\hline
\end{tabular}

I have 24 manuscripts published internationally.

Cite this article: Srichaikul B. The Effect of Lentinus squarrosulus, (Mont.) Consumption on the treatment of Gastritis in Male Wistar Rats. Pharmacogn J. 2020;12(5):1093-6. 